\title{
Multivariate approach to milk production and some physiological traits of crossbred dairy cows
}

\section{Abordagem multivariada da produção de leite e algumas características fisiológicas de vacas leiteiras mestiças}

\author{
Débora Andréa Evangelista Façanha ${ }^{1}$; Josiel Borges Ferreira ${ }^{2 *}$; Benito Soto- \\ Blanco 3 ; Magda Maria Guilhermino4; Jacinara Hody Gurgel Morais Leite²; Kelly \\ Mary Nery ${ }^{5}$; Angela Maria de Vasconcelos ${ }^{6}$; Wirton Peixoto Costa ${ }^{1}$
}

\begin{abstract}
The aim of the present study was to evaluate the changes in physiological responses and serum biochemical panel in crossbred dairy cow populations kept in a hot climate environment. We used a population of 384 dairy cows of genetic groups $1 / 2$ Holstein $\times 1 / 2$ Guzerá $(n=105)$ and $3 / 4$ Holstein $\times$ $1 / 4$ Guzerá $(n=279)$ derived from the Brazilian semiarid region. The physiological responses analyzed were: respiratory rate (RR, movements/minute), rectal temperature $\left(\mathrm{RT},{ }^{\circ} \mathrm{C}\right)$, free thyroxine $\left(\mathrm{T}_{4}, \mu \mathrm{g} / \mathrm{mL}\right)$ and thyroid-stimulating hormone (TSH, $\mu \mathrm{UI} / \mathrm{mL}$ ). The values of RR, RT, $\mathrm{T}_{4}, \mathrm{TSH}$ and serum levels of glucose, cholesterol, total protein, urea and creatinine were determined and correlated with milk production for 305 days, correlation lying only with TSH. Significant differences were observed just in milk production, RR and TSH comparing the genetic groups $1 / 2$ Holstein $\times 1 / 2$ Guzerá and $3 / 4$ Holstein $\times$ $1 / 4$ Guzerá. In conclusion, $3 / 4$ Holstein $\times 1 / 4$ Guzerá cows showed higher thyroid activity and milk production than $1 / 2$ Holstein $\times 1 / 2$ Guzerá cows, and may therefore be a better option for dairy production systems in semiarid regions.
\end{abstract}

Key words: Adaptability. Genetic groups. Milk production. Semiarid region. TSH. Thyroxine.

\section{Resumo}

O objetivo do presente estudo foi avaliar as mudanças de algumas respostas fisiológicas e dos parametros bioquímicos séricos em vacas leiteiras mestiças mantidas em um ambiente de clima quente. Utilizou-se uma população de 384 vacas leiteiras de grupos genéticos $1 / 2$ Holstein $\times 1 / 2$ Guzerá $(n=105)$ e 3/4Holstein $\times 1 / 4$ Guzerá $(n=279)$ criadas no semiárido brasileiro. As respostas fisiológicas analisadas foram: frequência respiratória (RR, movimentos/minuto), temperatura retal $\left(\mathrm{RT},{ }^{\circ} \mathrm{C}\right)$, tiroxina livre $\left(\mathrm{T}_{4}\right.$, $\mathrm{ug} / \mathrm{mL}$ ) e hormônio estimulante da tireóide (TSH, $\mu \mathrm{UI} / \mathrm{mL}$ ). Os valores de RR, RT, TR, $\mathrm{T}_{4}, \mathrm{TSH}$ e níveis

\footnotetext{
1 Profs., Departamento de Ciências Animais, Universidade Federal Rural do Semi-Árido, UFERSA, Mossoró, RN, Brasil. E-mail: debora_ufersa@hotmail.com; wirton@ufersa.edu.br

2 Discentes, Pós-Graduação em Ciência Animal, PPGCA, Departamento de Ciências Animais, UFERSA, Mossoró, RN, Brasil. E-mail: jjosielborges@hotmail.com; narinhazootecnista@hotmail.com

3 Prof., Departamento de Clínica e Cirurgia Veterinária, Universidade Federal de Minas Gerais, UFMG, Belo Horizonte, MG, Brasil. E-mail: benito@vet.ufmg.br

4 Prof., Unidade Acadêmica Especializada em Ciências Agrárias, Universidade Federal do Rio Grande do Norte, UFRN, Natal, RN, Brasil. E-mail: magdaguilhermino@gmail.com

5 Eng ${ }^{\mathrm{a}}$ Agra , M.e em Produção Animal, Serviço de Aprendizagem Rural, SENAR, Natal, RN, Brasil. E-mail: kelymarynery@, hotmail.com

6 Prof ${ }^{a}$, Departamento de Zootecnia, Universidade Estadual Vale do Acaraú, UVA, Sobral, CE, Brasil. E-mail: angv06@hotmail.com

* Author for correspondence
}

Received: Oct. 24, 2016 Approved: June 13, 2017 
séricos de glicose, colesterol, proteínas totais, uréia, creatinina foram determinados e correlacionados com a produção de leite corrigida para os 305 dias, encontrando-se correlação apenas com TSH. Foram observadas diferenças significativas apenas na produção de leite, RR e TSH entre os grupos genéticos $1 / 2$ Holstein $\times 1 / 2$ Guzerá e $3 / 4$ Holstein $\times 1 / 4$ Guzerá. Concluiu-se que, vacas $3 / 4$ Holstein $\times 1 / 4$ Guzerá apresentaram maior atividade da tireóide e produção de leite do que as vacas $1 / 2$ Holstein $\times 1 / 2$ Guzerá, podendo ser uma melhor opção para sistemas de produção leiteira no semiárido.

Palavras-chave: Adaptabilidade. Grupos genéticos. Produção de leite. Região semiárida. TSH. Tiroxina

Milk production systems installed in the Brazilian semiarid region have been used on a large scale, in which the European breeds specialized in milk production are crossed with zebu breeds more suited to the climate of semiarid conditions. The result of this cross produces animals which are less productive, but more rustic and more adapted to the tropics, which increases the productivity and viability of dairy farming in the semiarid northeast (URBANO et al., 2015). When it comes to animal production, adaptation is not just survival, but also breeding and production consistent with their use in production systems. Dairy cattle raised in tropical climates often suffer from heat stress, due to their high productivity, undergoing physiological and behavioral changes, where high ambient temperatures, relative humidity and solar radiation hinder heat dissipation (ALFONZO et al., 2016).

Blood is the fluid connective tissue that gives an immediate indication of an animal's nutritional status at that point in time (SARKER et al., 2015). Blood profiles have often been used to assess nutritional status and physiological adaptation of dairy cows during lactation. These profiles have also been used to monitor the health of the herd, to find subclinical disease and investigate herd problems with metabolic diseases (PAYNE et al., 1970; ELLAH et al., 2015).

The aim of the present study was to evaluate the changes in physiological responses and serum biochemical panel in crossbred dairy cows kept in a hot climate environment. In this herd, the genetic groups were strictly controlled, as they were inserted in a breeding program which registered births and genealogy.
The experiment evaluated 384 dairy cows from two genetic groups: $1 / 2$ Holstein $\times 1 / 2$ Guzerá $(n=$ $105)$ and $3 / 4$ Holstein $\times 1 / 4$ Guzerá $(1 / 4)(n=279)$, from a commercial farm located in the city of Quixeramobim, central semiarid region of Ceará state, northeastern Brazil, for one year. During the experimental procedures, temperature varied from 28.6 to $39.5{ }^{\circ} \mathrm{C}$ (average of $34.02{ }^{\circ} \mathrm{C}$ ) and relative humidity ranged from 18 to $45 \%$ (average of 30.01 $\%$ ). The animals had an average production of 23 $\pm 1.44 \mathrm{~kg}$ of milk per day, were multiparous, in the same order of lactation (about $1 / 3$ of milk production) and fed on native pasture and supplementation with corn silage, concentrate and with water ad libitum.

The physiological responses analyzed were: respiratory rate (RR, movements/min), rectal temperature $\left(\mathrm{RT},{ }^{\circ} \mathrm{C}\right)$, free thyroxine $\left(\mathrm{T}_{4}, \mu \mathrm{g} / \mathrm{mL}\right)$ and thyroid-stimulating hormone (TSH, $\mu \mathrm{UI} / \mathrm{mL})$. The first variable collected in each animal was the RR, recorded through observation and direct counting of flank movements for $1 \mathrm{~min}$, adopting procedures that avoided stress of the animal. The RT was recorded through a digital clinical thermometer with a range up to $44{ }^{\circ} \mathrm{C}$, inserted directly into the animal's rectum, at an approximate depth of 10 $\mathrm{cm}$ for $3 \mathrm{~min}$ in direct contact with the mucosa. Blood samples were collected from the jugular vein into vacuum tubes without anticoagulant, centrifuged at $3000 \mathrm{rpm}$ for $5 \mathrm{~min}$ and frozen at -20 ${ }^{\circ} \mathrm{C}$. The levels of $\mathrm{T}_{4}$ and TSH were measured by an ELISA automatic analyzer (Elisys Uno, Human, Wiesbaden, Germany) with specific commercial kits (RPC Diagnostic Systems, Nizhny Novgorod, Russia), in the Laboratory of the Research Study Center in Small Ruminants in the Universidade Federal Rural do Semi-Árido (UFERSA). 
Analysis of the serum biochemical panel was performed using specific commercial kits, with an automated clinical chemistry analyzer (HumaStar 80, Wiesbaden, Germany) and specific commercial kits (VIDA Biotecnologia) to determine serum glucose levels $(\mathrm{mg} / \mathrm{dL})$, cholesterol $(\mathrm{mg} / \mathrm{dL})$, urea $(\mathrm{mg} / \mathrm{dL})$, creatinine $(\mathrm{mg} / \mathrm{dL})$, total proteins $(\mathrm{g} / \mathrm{dL})$ and globulin $(\mathrm{g} / \mathrm{dL})$.

The effect of the genetic groups $1 / 2$ Holstein $\times \quad 1 / 2$ Guzerá and $3 / 4$ Holstein $\times 1 / 4$ Guzerá on physiological responses and concentrations of the serum biochemical panel were determined using Pearson's correlation coefficient, and the Duncan test was used to establish whether the correlation coefficient was significantly different from zero. The statistical model used was:

$$
Y_{\mathrm{ij}}=\mu+\mathrm{GG}_{\mathrm{i}}+e_{\mathrm{j}}
$$

$Y_{\mathrm{ij}} \quad$ Set of dependent variables

$\mu \quad$ Overall average of each variable

$\mathrm{GG}_{\mathrm{i}}$ Genetic groups $(1 / 2$ Holstein $\times 1 / 2$ Guzerá and $3 / 4$ Holstein $\times 1 / 4$ Guzerá)

$e_{\mathrm{i}}$ Random error associated with each observation

Statistical analyses were carried out using
Primer 6 (PRIMER-E Ltd, Plymouth, UK). To test the effect of genetic groups on studied variables, a distance-based permutation ANOVA was fitted. Principal component analysis was performed for each genetic group separately.

In Table 1, it can be seen that there were significant differences in milk production $(\mathrm{p}<0.0001)$, RR ( $\mathrm{p}$ $<0.0024)$ and TSH $(\mathrm{p}<0.0001)$ comparing the genetic groups $1 / 2$ Holstein $\times 1 / 2$ Guzerá and $3 / 4$ Holstein $\times 1 / 4$ Guzerá. The $3 / 4$ Holstein $\times 1 / 4$ Guzerá animals had an increased number of breaths and increased TSH secretion, possibly from higher milk production.

Assessing metabolic blood profiles may help in investigating herd problems by demonstrating the severity and timing of disturbances in energy metabolism (KANEKO et al., 2008). The serum levels of glucose, cholesterol, total protein, urea and creatinine found in this study were within the normal range for cattle (KANEKO et al., 2008), indicating that no abnormality occurred in the cows evaluated. The variation in the blood serum biochemistry panel (Table 1) did not show significant differences between the genetic groups $1 / 2$ Holstein $\times 1 / 2$ Guzerá and $3 / 4$ Holstein $\times 1 / 4$ Guzerá, and no association of these groups was found in the correlation analysis (Table 2).

Table 1. Physiological responses and serum biochemical panel and milk production for 305 days of dairy $1 / 2$ Holstein $\times 1 / 2$ Guzerá and $3 / 4$ Holstein $\times 1 / 4$ Guzerá crossbred cows kept in a hot environment in Brazil. Data are presented as mean followed by standard deviation.

\begin{tabular}{lccc}
\hline Variables & $1 / 2$ Holstein $\times 1 / 2$ Guzerá & $3 / 4$ Holstein $\times 1 / 4$ Guzerá & p value \\
\hline Milk production $(\mathrm{L})$ & $2.600 \pm 0.10$ & $3.770 \pm 0.06$ & $<0.0001^{* *}$ \\
$\mathrm{RR}($ movements $/ \mathrm{min})$ & $43.63 \pm 0.79$ & $46.47 \pm 0.49$ & $0.0024^{*}$ \\
$\mathrm{RT}\left({ }^{\circ} \mathrm{C}\right)$ & $39.42 \pm 0.04$ & $39.36 \pm 0.03$ & 0.2234 \\
$\mathrm{~T}_{4}(\mu \mathrm{g} / \mathrm{dL})$ & $1.83 \pm 0.12$ & $2.10 \pm 0.19$ & 0.2270 \\
$\mathrm{TSH}(\mu \mathrm{UI} / \mathrm{mL})$ & $1.27 \pm 0.12$ & $2.63 \pm 0.07$ & $<0.0001^{* *}$ \\
Glucose $(\mathrm{mg} / \mathrm{dL})$ & $52.30 \pm 1.42$ & $54.16 \pm 0.87$ & 0.2648 \\
Total proteins $(\mathrm{mg} / \mathrm{dL})$ & $6.70 \pm 0.10$ & $6.68 \pm 0.06$ & 0.8924 \\
Cholesterol $(\mathrm{mg} / \mathrm{dL})$ & $108.76 \pm 3.42$ & $110.99 \pm 2.10$ & 0.5789 \\
Urea $(\mathrm{mg} / \mathrm{dL})$ & $21.48 \pm 0.84$ & $21.79 \pm 0.51$ & 0.7475 \\
Creatinine $(\mathrm{mg} / \mathrm{dL})$ & $1.56 \pm 0.03$ & $1.47 \pm 0.02$ & $0.0254^{*}$ \\
\hline
\end{tabular}

Respiratory rate, RR; rectal temperature, RT; free thyroxine, $\mathrm{T}_{4}$; thyroid-stimulating hormone, $\mathrm{TSH}$.

* Significant difference $(\mathrm{p}<0.05)$ between groups; $* *$ significant difference $(\mathrm{p}<0.0001)$ between groups. 
Positive values were found only for TSH as a variable correlated with milk production for 305 days in the genetic group $1 / 2$ Holstein $\times 1 / 2$ Guzerá (as TSH increases, milk production follows the same manner) (Table 2). When an animal is exposed to an inappropriate environment, one of the first physiological responses is activation of the hypothalamic-pituitary-adrenal axis, which involves changes in the entire endocrine system (FAÇANHA et al., 2013). TSH is responsible for the stimulation and subsequent release of thyroid hormones $\left(\mathrm{T}_{3}\right.$ and $\left.\mathrm{T}_{4}\right)$, which together regulate cell metabolism that provides oxygen consumption and the power generation needed for tissue activities in the body (SANIN et al., 2016). Cows with higher milk potential $(3 / 4$ Holstein $\times 1 / 4$ Guzerá $)$ were more susceptible to the natural environment of warm weather to which they were subjected, explained by higher levels of TSH and $\mathrm{T}_{4}$; however, they showed higher average milk production compared to the $1 / 2$ Holstein $\times 1 / 2$ Guzerá animals. State that genetic variation is associated with the amount of milk production loss as well as being one of the success factors within a ruminant production system.

Table 2. Correlation between physiological responses and serum biochemical panel levels and milk production for 305 days in dairy $1 / 2$ Holstein $\times 1 / 2$ Guzerá and $3 / 4$ Holstein $\times 1 / 4$ Guzerá crossbred cows.

\begin{tabular}{|c|c|c|c|c|}
\hline \multirow{2}{*}{ Variables } & \multicolumn{2}{|c|}{$1 / 2$ Holstein $\times 1 / 2$ Guzerá } & \multicolumn{2}{|c|}{ 3/4Holstein × 1/4Guzerá } \\
\hline & $\mathrm{CC}$ & $\mathrm{p}$ value & $\mathrm{CC}$ & $\mathrm{p}$ value \\
\hline RR & -0.03 & 0.7347 & 0.01 & 0.8250 \\
\hline RT & 0.09 & 0.3837 & 0.06 & 0.3462 \\
\hline $\mathrm{T}_{4}$ & -0.21 & $0.0284^{*}$ & -0.04 & $0.5049 *$ \\
\hline TSH & 0.36 & $0.0002 *$ & 0.09 & 0.1452 \\
\hline Glucose & -0.03 & 0.7562 & -0.07 & 0.2210 \\
\hline Total proteins & 0.05 & 0.6433 & 0.02 & 0.6854 \\
\hline Cholesterol & -0.08 & 0.4067 & 0.15 & $0.0139 *$ \\
\hline Urea & -0.19 & 0.0574 & 0.04 & 0.4927 \\
\hline Creatinine & -0.07 & 0.4741 & 0.10 & 0.1128 \\
\hline
\end{tabular}

Respiratory rate, RR; rectal temperature, RT; free thyroxine, $\mathrm{T}_{4}$; thyroid-stimulating hormone, TSH; correlation coefficient, CC.

* Significant value $(\mathrm{p}>0.05)$.

In discriminant analysis of the genetic group $1 / 2$ Holstein $\times 1 / 2$ Guzerá (Figure $1 \mathrm{~A}$ ), the first two principal factors explained $38.67 \%$ of the total variation. The first principal factor was associated with RT, TSH and milk production, and these measures varied according to the genetic group. The second factor was mainly associated with the serum biochemical panel (creatinine, cholesterol and total protein). For the genetic group $3 / 4$ Holstein $\times 1 / 4$ Guzerá (Figure 1B), the first two principal factors explained $33.13 \%$ of the total variation. The first principal factor was positively associated with
RR and milk production and negatively with RT. The second factor was mainly associated with the hormone $\mathrm{T}_{4}$.

In this study, the animals are considered to have high productive potential, with higher metabolic rates and a likely increase in stimulation of the thyroid to increase secretion of its hormones, since these have a catabolic effect, which contributes to the increased availability of nutrients for the synthesis of milk. It is likely that these animals already have morphophysiological features that help them to adapt to the environment, so changes 
were not observed in the relationship between metabolites and hormones. Normal and similar concentrations of free $T_{4}$ between genetic groups suggest that thyroid activity was not changed and that the hormone was probably required at levels in the same order of magnitude for the formation of the $\mathrm{T}_{3}$ molecule whose biological activity is observed at the level of the target tissue.

Many mechanisms are used to establish metabolic homeostasis; however, almost all influence the physiology, which involves changes in production functions. According to Façanha et al. (2013), selecting animals adapted to the particularities of the breeding environment means working with those closest to homeostasis, which must be confirmed by normal physiological indicators such as body temperature, hormone profile, biochemical and hematological indicators, reproductive functions and milk production, among others.

Figure 1. Discriminant analysis of physiological responses and serum biochemical panel in different genetic groups of dairy cows. (A) $1 \frac{1}{2}$ Holstein $\times 1 / 2$ Guzerá; (B) 3/4Holstein $\times 1 / 4$ Guzerá. Respiratory rate, RR; rectal temperature, RT; free thyroid, $\mathrm{T}_{4}$; thyroid-stimulating hormone, $\mathrm{TSH}$; glucose, Glu; cholesterol, Chol; urea, Urea; creatinine, Creat; total proteins, TP.

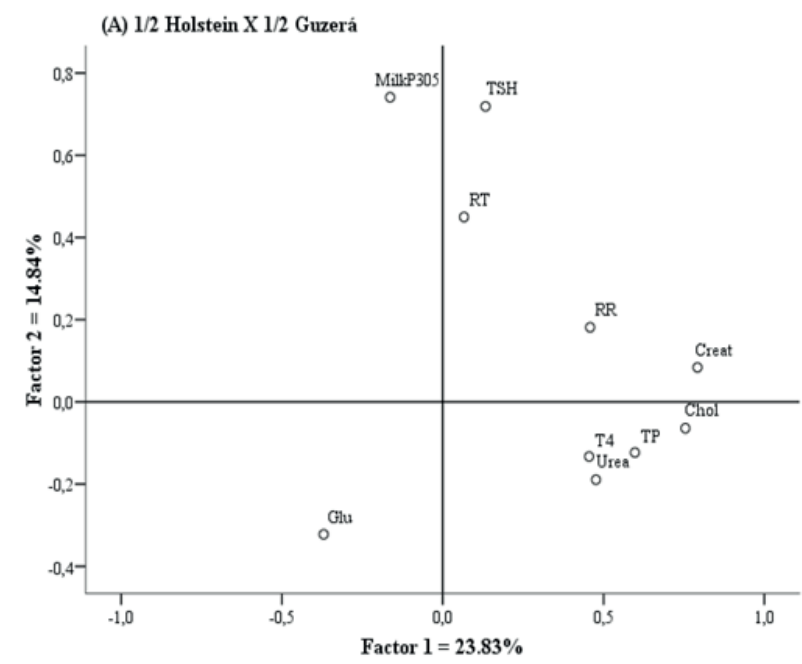

It was concluded that $3 / 4$ Holstein $\times 1 / 4$ Guzerá cows showed higher thyroid activity and milk production than $1 / 2$ Holstein $\times 1 / 2$ Guzerá cows. The higher milk production of $3 / 4$ Holstein $\times 1 / 4$ Guzerá cows can be attributed to a higher proportion of the European breed, associated with the rusticity of zebu cattle, tracing a better phenotype for milk production in hot environments. The normal values of biochemical, hormonal and thermoregulatory responses confirmed the maintenance of homeostasis in both genetic groups, which may be an advantageous option for dairy systems in hot and semiarid environments.

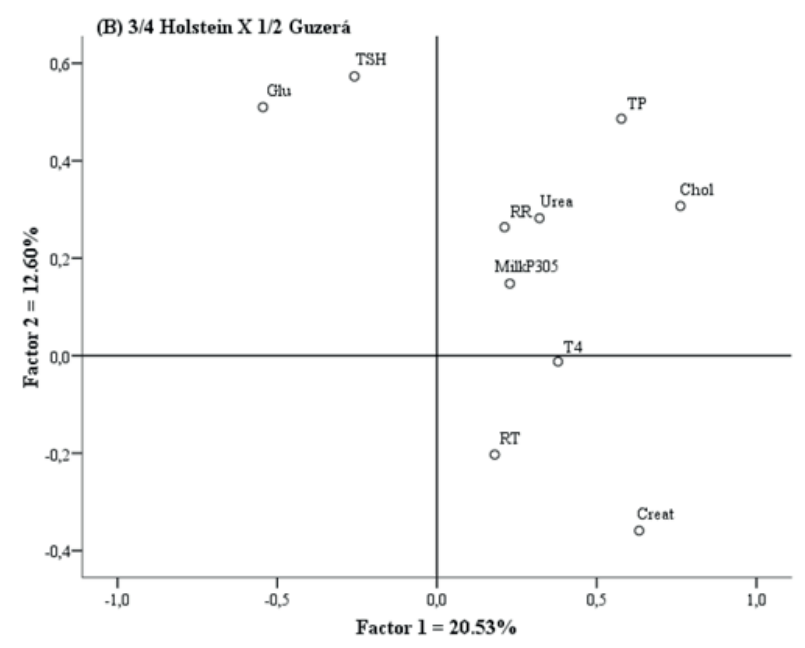

\section{Acknowledgement}

The authors would like to thank the owner of Canhotinho Farm and the entire team of technicians, students, teachers and employees who helped with the research.

\section{Ethics committee}

CEUA-UFERSA, review number 34/2014 and process number 23091.003895/2014-71. 


\section{Conflicts of interest}

There are no conflicts of interest.

\section{References}

ALFONZO, E. P. M.; SILVA, M. V. G. B.; DALTRO, D. S.; STUMPF, M. T.; DALCIN, V. C.; KOLLING, G.; FISCHER, V.; MCMANUS, C. M. Relationship between physical attributes and heat stress in dairy cattle from different genetic groups. International Journal of Biometeorology, v. 60, n. 2, p. 245-253, 2016.

ELLAH, M. R. A.; OKADA, K.; SHIMAMURA, S.; KOBAYASHI, S.; SATO, R.; YASUDA, J. Comparison between serum and saliva biochemical constituents in dairy cows during lactation and dry period. Journal of Advanced Veterinary Research, Egypt, v. 5, n. 3, p. 143$150,2015$.

FAÇANHA, D. A. E.; FERREIRA, D. C.; MORAIS, J. H. G.; VASCONCELOS, A. M.; PEIXOTO, W. C.; GUILHERMINO, M. M. Tendências metodológicas para avaliação da adaptabilidade ao ambiente tropical. Revista Brasileira de Saúde e Produção Animal, Salvador, v. 14, n. 1, p. 91-103, 2013.
KANEKO, J. J.; HARVEY, J. W.; BRUSS, M. L. Clinical biochemistry of domestic animals. San Diego: Academic Press, 2008. 928 p.

PAYNE, J. M.; DEW, A. M.; MANSTON, R.; FAULKS, M. The use of a metabolic profile test in dairy herds. Veterinary Record, London, v. 87, n. 6, p. 150-158, 1970.

SANIN, Y. L.; CABRERA, A. M. Z.; MORALES, A. M. T. Adaptive responses to thermal stress in mammals. Revista de Medicina Veterinária, Bogotá, v. 31, n. 31, p. 121-135, 2016.

SARKER, M. D. S.; AHADUZZAMAN, M. D.; SAYED, M. D. A.; SARKER, R.; NANNO, M. A.; MANNAN, A.; HOSSAIN, M. B. Comparison of some serum biochemical parameters between lactating and non-lactating dairy cows in selected dairy farms of Chittagong district of Bangladesh. Asian Journal of Medical and Biological Research, Bangladesh, v. 1, n. 2, p. 259-264, 2015.

URBANO, S. A.; GUILHERMINO, M. M.; FERREIRA, J. B.; FAÇANHA, D. A. E.; RANGEL, A. H. N.; GOMES, J. T. Comportamento de vacas leiteiras em sistema de ordenha manual no semiárido. Acta Veterinaria Brasilica, Mossoró, v. 9, n. 4, p. 348-353, 2015. 